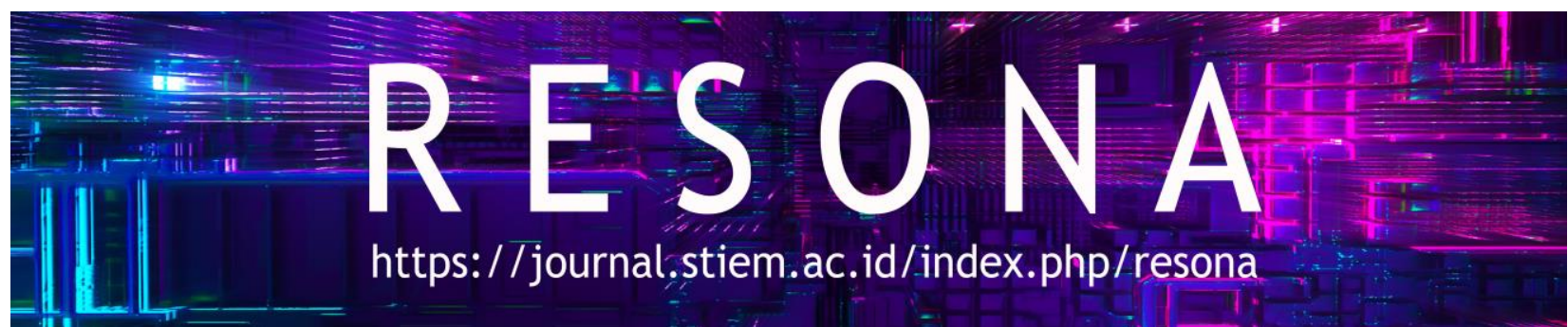

\title{
MAKSIMALISASI ALAT PERAGA EDUKATIF SEBAGAI UPAYA PENGEMBANGAN POS PAUD DI WILAYAH KELURAHAN MERJOSARI KOTA MALANG
}

${ }^{1}$ Adya Hermawati, ${ }^{2}$ Choirul anam

${ }^{1,2}$ Universitas Widyagama Malang

\author{
INFO NASKAH \\ Diserahkan 04 Desember 2019 \\ Diterima \\ 11 Desember 2019 \\ Diterima dan Disetujui 24 \\ Desember 2019
}

Kata Kunci:

Alat Peraga Edukatif Motorik, Pos PAUD

\section{Abstract:}

Educative Motoric Teaching Aids,

PAUD Post

\begin{abstract}
ABSTRAK
Peran Pos Pendidikan Anak Usia Dini (PAUD) signifikan dalam masyarakat karena dikelola dengan prinsip "dari, oleh dan untuk masyarakat". Namun demikian, Pos Paud yang ada di RW wilayah Kelurahan Merjosari Malang, dalam prakteknya beberapa masih menemui banyak kendala. Salah satu penyebabnya adalah keterbatasan sarana dan prasarana. Kegiatan Pengabdian Masyarakat ini dilakukan untuk memberikan solusi alternatif terhadap beberapa permasalahan yang dihadapi oleh dua Pos PAUD di wilayah Kelurahan Merjosari Malang. Hasil yang dicapai dalam pelaksanaan Iptek Bagi Masyarakat (Pengabdian Masyarakat) adalah berupa alat peraga edukatif/APE motorik kasar (outdoor), pagar besi, meja dan kursi warna warni standard untuk siswa usia dini kususnya Pos Paud, loker warna warni, lemari arsip untuk menyimpan dan mengamankan dokumen dokumen Pos Paud, kursi guru, meja pentas kreasi siswa, pelatihan manajemen pengelolaan dan pengembangan Pos PAUD dengan konsep POAC, alat peraga edukatif/APE motorik halus ( indoor), pelatihan dan pendampingan tata kelola administrasi keuangan oraganisasi Pos PAUD, serta pembuatan buku panduan ISBN tentang Manajemen Pengelolaan dan pengembangan Organisasi (Pos Paud) berbasis Planning, Organizing, Actuating and Controlling (POAC). saran yang dapat membangun dalam peningkatan kinerja yaitu agar Pos Paud yang ada di wilayah RW di Kelurahan Merjosari Malang (Pos Jaya Kusuma maupun Mawar Merah) benar-benar dapat memanfaatkan bantuan dengan merawat bantuan sarana dan prasarana yang telah diberikan serta dapat mengaplikasikan teori-teori dalam pelatihan.
\end{abstract}

Abstract. Abstract. The Early Childhood Education Post (PAUD) role is significant in the community because it managed by the principle of "from, by, and for the community." However, Pos Paud, which is in the RW area of Merjosari Malang, in practice, some still encounter many obstacles. Community Service Activities are carried out to provide alternative solutions to some of the problems faced by two PAUD posts in the Merjosari Kelurahan region of Malang. The results achieved in the implementation of Science and Technology for the Community (Community Service) were educative props/rough motorized APE (outdoor), iron fences, colorful colored tables, and chairs for early childhood students specifically the Pos Paud, bright lockers, file cabinets to store and secure Pos Paud documents, teacher chairs, student creation tables, management training and development of PAUD Posts with POAC concepts, educative props / excellent motorized APE (indoor), training and assistance in financial administration governance of PAUD Post organizations. The result also included the making of ISBN handbook on Management of Organizational and Organizational Development (Pos Paud) based on Planning, Organizing, Actuating, and Controlling (POAC). The suggestions for the Pos Paud in the RW area in Merjosari Malang (Pos Jaya Kusuma and Mawar Merah) were to keep improving their performance and keep the care of facilities and infrastructure that have been given and can apply the theories in training 


\section{Pendahuluan}

Keberadaan Pos PAUD di wilayah kelurahan Merjosari sebagai salah satu bentuk Satuan PAUD Sejenis (SPS) dimaksudkan untuk menjembatani kebutuhan layanan pendidikan ditingkat kelurahan yang berpusat di setiap RW. Berdasarkan dari hasil survei lapangan sebelum program ini dilakukan, Pos PAUD di wilayah kelurahan Merjosari diperuntukkan bagi masyarakat yang belum siap mengikutsertakan anaknya dalam pelayanan PAUD formal yang lebih intensif, baik karena alasan biaya, maupun faktor lainnya. Pos PAUD ditujukan utamanya bagi masyarakat tidak mampu untuk mengikutsertakan anaknya dalam layanan PAUD. Satuan seperti Pos PAUD sejenis bentuk lain yang sederajat dengan PAUD. Bedanya, PAUD sifatnya lebih intensif, relatif komersial/profit oriented, sifat penyelenggaraannya adalah formal. Sedangkan Pos PAUD adalah program layanan pendidikan yang penyelenggaraannya adalah non formal (Dirjen paud,2013), diintegrasikan dengan program Bina Keluarga Balita (BKB) dan Posyandu balita, menjadi satu kesatuan. Dari sebaran wilayah yang meliputi 12 RW di kelurahan Merjosari terindentifikasi ada 8 Pos PAUD (Pos Pendidikan Anak Usia Dini).

Dari hasil survey lapangan, hadirnya Pos PAUD di wilayah Kelurahan Merjosari, ternyata memberi dampak yang positif bagi masyarakat tidak mampu. Masyarakat merasa terbantu dalam mengasuh dan mendidik tumbuh kembang anak-anaknya. Dilain hal, UU Sisdiknas No. 20 Tahun 2003 disebutkan bentuk Pos PAUD (UUD Sisdiknas, 2003) yang mengcover layanan PAUD diintegrasikan dengan program Bina Keluarga Balita (BKB) dan posyandu balita. Peran Pos PAUD, signifikan dalam masyarakat, karena dikelola dengan prinsip "dari, oleh dan untuk masyarakat", dibentuk atas kesepakatan masyarakat dan dikelola berdasarkan azaz gotong royong, kerelaan, dan kebersamaan, sangat berpotensi dapat berkembang menjadi PAUD, akan tetapi perkembangan ini mungkin luput dari stakeholder yang terkait. Setelah terbentuknya Pos PAUD langkah lebih lanjut, layaknya harus diperhatikan perkembangannya, hal ini perlu dilaksanakan agar membantu pendataan dan mengurangi disparitas layanan Pos PAUD antara daerah perkotaan, daerah pinggiran kota dan daerah pedesaan. Mengingat karakteristik wilayah pos Paud ini (Kelurahan Merjosari) berjarak kurang lebih 15 kilometer dari pusat kota, kategori masuk wilayah Kotamadya, namun letaknya di ujung paling barat perbatasan dengan kecamatan Sengkaling Kabupaten Malang. Lebih untuk menjadi perhatian pula bahwa terdapat beberapa wilayah RW di Kelurahan Merjosari dengan kondisi penduduk taraf pendidikan rendah, mata pencaharian mayoritas buruh, pembantu rumah tangga, tukang batu, pegawai golongan I, tukang becak, jualan bakso dorong dengan modal pas pasan. Sehingga kondisi tersebut berdampak pada pendapatan relatif rendah yang diterima mereka per bulan. Hal terkait berdampak pula pada keterbatasan kemampuan untuk sekolahkan anak usia dini mereka pada Playgroup/PAUD swasta yang sudah formal.

Namun demikian, Pos Paud wilayah RW di Kelurahan Merjosari, berupaya maksimal melaksanakan prinsip dasar yang terstandard, meski prakteknya masih menemui banyak kendala, salah satu penyebabnya adalah: 1) keterbatasan penunjang sarana pendidikan untuk memotivasi motorik kasar siswa usia dini; 2) minimnya berbagai macam APE; 3) tidak adanya meja kursi yang terstandart untuk siswa usia dini; 4) optimalisasi kualitas pembelajaran dan kulitas manajemen belum maksimal; 5) rendahnya tata kelola adimistrasi keuangannya Pos Paud; 6) belum adanya pedoman untuk pelaksanaan lembaga dan forum yang menjembatani segala kebutuhan maupun solusi dari permasalahan yang muncul dalam Pos PAUD. Dari keterbatasan yang ada, menyebabkan lembaga ini berkembang kurang optimal layaknya lembaga pendidikan. 
Dari beberapa masalah yang menjadi kendala tersebut, maka menjadi perlu adanya sebuah strategi mengoptimalkan kerja sama pada semua lini, agar Pos Paud di wilayah Kelurahan Merjosari, memiliki kompetensi standard dan dapat bersaing menjadi Pos Paud yang berbasis kualitas meskipun sebagai organisasi atau lembaga pendidikan yang non formal. Di lain hal pendidikan anak usia dini adalah urgen, namun sayangnya sampai saat ini posisi Pos PAUD di Wilayah Kelurahan Merjosari masih terasa termajinalkan apabila dibanding dengan PAUD yang bukan dari rintisan BKB maupun Posyandu Balita. Alasannya antara lain adalah fasilitas yang dimiliki oleh Pos PAUD kurang lengkap, tenaga pendidik kurang kompeten dan tempat yang kurang memadai. Kendala-kendala inilah banyak dijumpai di berbagai daerah yang terdapat Pos PAUD termasuk di Pos PAUD Wilayah Kelurahan Merjosari. Pos PAUD masih kalah bersaing dengan PAUD swasta. Disisi lain meskipun SPP per siswa rata rata Rp. 10.000 per bulan dan pendidik/guru tidak dibayar, namun tetap berupaya bagaimana Pos PAUD dengan prinsip mudah, murah dan bermutu dapat bersaing dengan PAUD swasta. Sampai saat ini upaya untuk melaksanakan program Pos PAUD antara lain ikutsertakan kader dalam pelatihan baik yang diselenggarakan oleh Tim Penggerak PKK Kota Malang, Tim Penggerak PKK Provinsi, maupun pelatihan pelatihan yang diadakan oleh satuan lembaga pendidikan tinggi. Adapun data terakhir Pos PAUD yang sudah terbentuk sebanyak 219 dari 306 kelurahan di Kota Malang.

\section{Masalah}

Menurut Al Rasyid (2008) Pada dasarnya permasalahan yang dihadapi mitra sangat beragam dan saling bersinergi antara permasalahan yang satu dengan lainnya. Namun demikian untuk mempermudah solusinya, maka permasalahan mitra dikelompokkan menjadi tiga aspek utama yaitu permasalahan fasilitas sarana prasarana, permasalahan manajemen, permasalahan pelayanan.

a. Permasalahan Fasilitas Sarana dan Prasarana, walaupun dari hasil analisis situasi ke 2 mitra mempunyai kondisi yang sedikit berbeda, namun setelah ditelaah lebih seksama maka secara garis besar permasalahannya yang terjadi hampir sama. Permasalahan fasilitas terdiri dari:

1. Masalah kurangnya fasilitas bermain siswa yang berbentuk alat peragaedukatif/APE. Diharapkan dengan alat peraga edukatif yang terstandart akan meningkatkan kualitas maupun kemampuan siswa menjadi lebih maju. Kondisi Pos JAYA KUSUMA maupun MAWAR MERAH menunjukkan bahwa masih diperlukan APE dan alat penunjang motivasi motorik kasar untuk siwa usia dini.

2. Masalah masih belum mempunyai penunjang proses belajar mengajar yang berupa, meja dan kursi standart untuk siswa usia dini, lemari untuk arsip administrasi, loker tempat untuk kerapian mainan, meja kursi guru, komputer sebagai sarana membuat administrasi siswa maupun adiministrasi keuangan. Siswa yang selama ini duduk di lantai yang beralaskan karpet.

\section{b. Permasalahan Manajemen Permasalahan}

Pengertian lain dari manajemen berasal dari bahasa Inggris "administration" sebagai "the management of executive affairs". Dengan batasan pengertian seperti ini maka manajemen manajemen disinonimkan dengan "management" suatu pengertian dalam lingkup yang lebih luas (Arikunto \& Yuliana, 2008). Dalam hal ini masalah manajemen untuk kedua mitra adalah: 
1. Masalah manajemen mutu pembelajaran kedua mitra Pos PAUD belum adanya kendali kualitas. Belum adanya evaluasi program yang fokus terhadap Pos PAUD, Sehingga pengelola atau penyelenggara Pos PAUD kurang mengerti langkah-langkah apa yang harus diambil agar Pos PAUDnya terus berkembang kualitasnya.

2. Belum dilakukan pengarsipan yang tertib dan rapi, tatakelola administrasi keuangan per periode perlu pembenahan. Hal inilah yang menyebabkan manajemen untuk perkembangan Pos PAUD kurang optimal.

3. Keterbatasan sistem promosi sederhana dengan selebaran guna menawarkan Pos PAUD ke warga RW setempat dan RW tetangga maupun masyarakat wilayah sekitar.

c. Permasalahan Pelayanan,dari dua aspek permasalahan fasilitas sarana prasarana dan permasalahan manajemen, menjadi dampak pada permasalahan keterbatasan pelayanan pengelola dan pendidik untuk pelayanan terhadap pengguna/siswa, karena menjadi terbatasnya pelayanan asupan pendidikan pada siswa. Jadi keterbatasan sarana prasarana maupun pengetahuan manajemen organisasi pengelola pos Paud menjadi urgent untuk harus segera diberikan solusi, agar pelayanan kepada pengguna/siswa dan orang tua siswa menjadi maksimal.

\section{Metode}

Menurut Sugiyono (2008), metode penelitian pada dasarnya merupakan cara ilmiah untuk mendapatkan data dengan tujuan dan kegunaan tertentu. Berdasarkan hal tersebut terdapat empat kata kunci yang perlu diperhatikan yaitu cara ilmiah, data, tujuan dan kegunaan. Cara ilmiah berarti kegiatan penelitian itu didasarkan pada ciri-ciri keilmuan yang rasional, empiris, dan sistematis. Berdasarkan pemaparan tersebut dapat disimpulkan bahwa metode penelitian adalah suatu cara ilmiyah yang digunakan untuk memperoleh data sesuai dengan telaah penelitian dengan tujuan dan kegunaan tertentu. Oleh karena itu, untuk mencari solusi masalah yang dihadapi oleh mitra metode pendekatan dilakukan sesuai dengan masing-masing permasalahan, baik yang menyangkut fasilitas sarana dan prasarana, manajemen maupun pelayanan. Dalam pengabdian masyarakat ini, penulis melaksanakan kegiatan berdasarkan pada direktorat riset dan pengabdian kepada masyarakat (2016), sebagai panduan pelaksanaan penelitian dan pegabdian kepada masyarakat di perguruan tinggi.

\section{Solusi Yang Ditawarkan}

Dari permasalahan mitra maka ditawarkan solusinya dengan metode pendekatan yang tepat sehingga permasalahan yang ada dapat teratasi dengan baik. Solusi yang disepakati 
bersama dengan mitra dari persoalan prioritas, yang telah disesuaikan dengan departemen logistik pemerintahan (2012), adalah:

1. Minimnya fasilitas untuk penyampaian materi pelajaran yang berbentuk alat peraga edukatif/APE maupun alat penunjang motorik kasar sehingga belum mampu meningkatkan kualitas maupun kompetensi siswa Pos PAUD. Untuk itu solusi adalah mendesain dan membuat alat penunjang motorik kasar (berupa ayunan, plurutan, tangga motorik/panjat laba laba, jungkitan, tangga majemuk, panjatan globe, papan peluncur, titian keseimbangan) dan alat peraga pendidikan sebagai upaya meningkatkan proses pembelajaran dan kompetensi.

2. Siswa selama ini duduk di lantai beralaskan karpet karena masih belum mempunyai penunjang proses belajar mengajar yang berupa, tempat duduk dan meja warna warni terstandart untuk siswa usia dini, Untuk itu solusi adalah mendesain dan membuat sarana meja dan kursi terstandart untuk siswa usia dini sebagai sarana yang akan memberikan kenyamanan dalam proses pembelajaran Pos PAUD.

3. Masih belum tertata pengarsipan tatakelola administrasi pos Paud karena tidak dimilikinya tempat pengarsipan yang layak dan memadahi. Selain itu belum dimilikinya sarana sebagai tempat untuk alat peraga pendidikan (sentra balok, sentra matematika, sentra peran). Untuk itu solusi adalah mendesain dan membuat sarana tempat pengarsipan dokumen dan tempat untuk alat peraga pendidikan, berupa loker loker warna warni cantik dan menarik.

4. Pengelolaan Pos PAUD belum terstruktur dan sistematis sehingga perlu optimalisasi muatan pengetahuan tentang pengelolaan organisasi. Untuk itu diperlukan solusi melalui pelatihan dan pendampingan terkait konsep Planning, Organizing, Actuating and Controlling berbasis pembelajaran pada anak usia dini.

5. Konteks penataan administrasi keuangan belum optimal. Untuk itu diperlukan solusi melalui pendampingan dan pelatihan kelayakan administrasi kususnya administrasi keuangan.

6. Belum maksimalnya pelayanan pendidikan kepada pengguna/siswa, disebabkan manajemen pengelolaan pengembangan organisasi belum optimal. Pengelola Pos Paud belum mempunyai panduan manajemen pengelolaan pengembangan organisasi pendidikan usia dini yang bisa dijadikan pegangan untuk meningkatkan tatakelola organisasi pos Paud. Untuk itu diperlukan solusi buku pedoman/ buku panduan Manajemen Pengelolaan dan pengembangan Organisasi (Pos Paud) berbasis Planning, Organizing, Actuating and Controlling (POAC).

\section{Rencana Kegiatan}

Rencana kegiatan yang berupa langkah-langkah solusi untuk mengatasi masalahsesuai dengan pedoman penyaluran dana bantuan kelembagaan Pendidikan anak usia dini (2009) sebagai berikut:

1. Koordinasi dan diskusi antar anggota tim dengan mitra. Hal ini dimaksudkan untuk mendapatkan masukan dan gagasan yang digunakan untuk implementasi program ini. Penyamaan persepsi dan langkah gerak dalam pelaksanaan program ini menjadi penting dengan cara kerja yang kolegial seluruh anggota tim dan mitra.

2. Merancang pengadaan alat beserta spesifikasinya, dan sekaligus uji coba, yaitu meliputi:

a. Merancang pengadaan alat penunjang motorik kasar berupa: ayunan, plurutan, tangga 
motorik/panjat laba laba, jungkitan. Sementara atas permohonan dan pengajuan dari mitra untuk APE motorik yang lain yang tertera di proposal meliputi: tangga majemuk, panjatan globe, papan peluncur, titian keseimbangan, agar diganti dengan pagar besi warna warni sebagai pagar mengelilingi area bermain outdoor. Pagar besi tersebut ditujukan untuk melindungi atas keamanan siswa pos paud. Mengingat posisi tempat area sarana bermain outdoor siswa pos paud berdekatan dengan jalan raya. Atas permintaan Mitra dengan kesepakatan tim pelaksana, maka pengajuan mitra tersebut, diterima oleh Tim Pelaksana mengingat keberadaan pagar besi untuk keamanan siswa sangat urgen.

b. Merancang pengadaan alat sarana meja dan kursi warna warni terstandart untuk siswa usia dini sebagai sarana yang akan memberikan kenyamanan dalam proses pembelajaran Pos PAUD. Karena siswa selama ini duduk di lantai beralaskan karpet karena masih belum mempunyai penunjang proses belajar mengajar yang berupa, tempat duduk dan meja terstandart untuk siswa usia dini.

c. Merancang pengadaan sarana tempat pengarsipan dokumen dan tempat untuk alat peraga pendidikan berupa loker-loker warna warni cantik dan menarik serta lemari arsip/dokumen. Karena masih belum tertata pengarsipan tatakelola administrasi pos Paud, tidak dimilikinya tempat pengarsipan yang layak dan memadahi, belum dimilikinya sarana sebagai tempat untuk alat peraga pendidikan (sentra balok, sentra matematika, sentra peran).

d. Merencanakan dan mengkonsep materi yang dibutuhkan untuk pelatihan dan pendampingan terkait konsep Planning, Organizing, Actuating and Controlling berbasis pembelajaran pada anak usia dini. Karena pengelolaan Pos PAUD belum terstruktur dan sistematis sehingga perlu optimalisasi muatan pengetahuan tentang pengelolaan organisasi.

e. Merencanakan dan mengkonsep materi yang dibutuhkan untuk pelatihan dan pendampingan kelayakan administrasi kususnya administrasi keuangan. Karena penataan administrasi keuangan belum optimal.

f. Merencanakan dan mengkonsep materi yang dibutuhkan untuk menyusun buku pedoman/buku panduan Manajemen Pengelolaan dan pengembangan Organisasi (Pos Paud) berbasis Planning, Organizing, Actuating and Controlling (POAC). Karena belum maksimalnya pelayanan pendidikan kepada pengguna/siswa, disebabkan manajemen pengelolaan pengembangan organisasi belum optimal. Pengelola Pos PAUD belum mempunyai panduan manajemen pengelolaan pengembangan organisasi pendidikan usia dini yang bisa dijadikan pegangan untuk meningkatkan tatakelola organisasi Pos PAUD.

\section{Partisipasi Mitra}

Bentuk partisipasi mitra dalam pelaksanaan program ini adalah sebagai berikut:

1. Mitra turut serta dalam diskusi untuk memberikan informasi tentang berbagai persoalan dan menyampaikan kesulitan yang dihadapi terkait permasalahan sarana prasarana, permasalahan manajemen, permasalahan pelayanan untuk pengguna/siswa. Tindak lanjut diskusi, menjadi program implementasi solusi yang nyata untuk mengatasi permasalahan, sehingga luaran yang dihasilkan program ini benar-benar bermanfaat dan sesuai dengan harapan mitra. 
2. Ikut menyiapkan sarana dan prasarana dalam uji coba alat yang telah dihasilkan bersama dengan anggota tim. Mengikuti pelatihan dan tutorial sehingga mengerti tentang manajemen pengelolaan organisasi pendidikan seperti Pos PAUD, mengikuti pelatihan dan tutorial tentang administrasi pembukuan yang tersistematis. 3)Bersedia bekerja sama dengan tim secara berkelanjutan bilamana diperlukan.

\section{Justifikasi Pengusul Bersama Mitra}

Skala prioritas yang menjadi kesepakatan antara tim pengusul dengan mitra adalah:

1. Minimnya fasilitas untuk penyampaian materi pelajaran yang berbentuk alat peraga edukatif/APE maupun alat penunjang motorik kasar, yang belum mampu meningkatkan kualitas maupun kompetensi siswa Pos PAUD. Untuk itu diperlukan sarana penunjang motorik kasar, dan sarana penunjang peraga pendidikan untuk anak usia dini sebagai sarana untuk meningkatkan proses pembelajaran dan kompetensi.

2. Masih belum mempunyai penunjang proses belajar mengajar yang berupa, tempat duduk dan meja warna warni standart untuk siswa usia dini. Siswa selama ini duduk di lantai beralaskan karpet. Untuk itu diperlukan meja dan kursi warna warni standart untuk siswa usia dini sebagai sarana yang akan memberikan kenyamanan dalam proses pembelajaran Pos PAUD.

3. Masih belum tertata pengarsipan tatakelola administrasi pos Paud karena tidak dimilikinya tempat pengarsipan yang layak dan memadahi. Selain itu belum dimilikinya sarana sebagai tempat untuk alat peraga pendidikan (sentra balok, sentra matematika, sentra peran). Sehingga sangat dibutuhkan sarana pengarsipan tertata tatakeloa administrasi sarana sebagai tempat untuk alat peraga pendidikan (sentra balok, sentra matematika, sentra peran). untuk Pos PAUD.

4. Pengelolaan Pos PAUD belum terstruktur dan sistematis sehingga perlu optimalisasi muatan pengetahuan tentang pengelolaan organisasi. Oleh karena itu dibutuhkan asupan ilmu (pelatihan) terkait konsep Planning, Organizing, Actuating and Controlling (POAC) berbasis pembelajaran pada anak usia dini.

5. Belum optimal penataan administrasi keuangan sehingga diperlukan pendampingan dan pelatihan kelayakan administrasi kususnya administrasi keuangan.

6. Belum mempunyai panduan mengelola organisasi pendidikan usia dini yang bisa di jadikan pegangan Pengelola Pos Paud untuk meningkatkan tatakelola organisasi pos Paud. Untuk itu dibutuhkan semacam buku panduan Manajemen Pengelolaan dan pengembangan Organisasi (Pos PAUD) berbasis Planning, Organizing, Actuating and Controlling (POAC).

\section{Hasil dan Pembahasan}

Pos PAUD berfungsi memberikan pendidikan sejak dini \& membantu meletakkan dasar ke arah pengembangan sikap, perilaku, perasaan, kecerdasan, sosial \& fisik yg diperlukan dalam menyesuaikan diri dengan lingkungan yang berpengaruh terhadap tumbuh kembang anak usia dini. Gambar 1 adalah lokasi dan bagian dari kegiatan Pos PAUD "JAYA KUSUMA" dan Pos PAUD "MAWAR MERAH". 

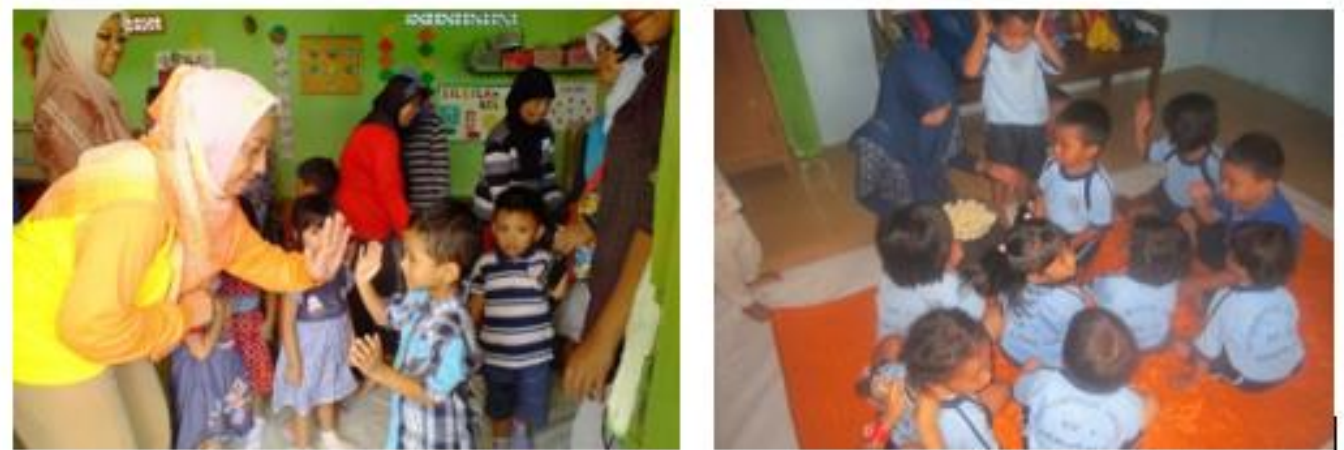

Gambar 1. Kegiatan Pos PAUD

Kegiatan Pos PAUD, bidang pengembangan yang berkaitan adalah: 1) Kesehatan, dimana sumber daya manusia yang berkualitas sejak awal merupakan modal dasar bagi proses tumbuh kembang anak untuk selanjutnya. Pertumbuhan anak ditandai dengan adanya peningkatan tinggi badan, berat badan, dan lingkar kepala;2) Psikososial yang mana berfungsi mengoptimalkan tumbuh kembang anak.

Gambar 2 adalah BKB (Bina Keluarga Balita) yang merupakan bagian dari kegiatan Pos PAUD dimana ibu/orang tua dari siswa mendapatkan beberapa asupan ilmu yang terkait dengan pendidikan dan mendidik anak siswa usia dini sebagai kegiatan yang intensif dan rutin secara periodik.
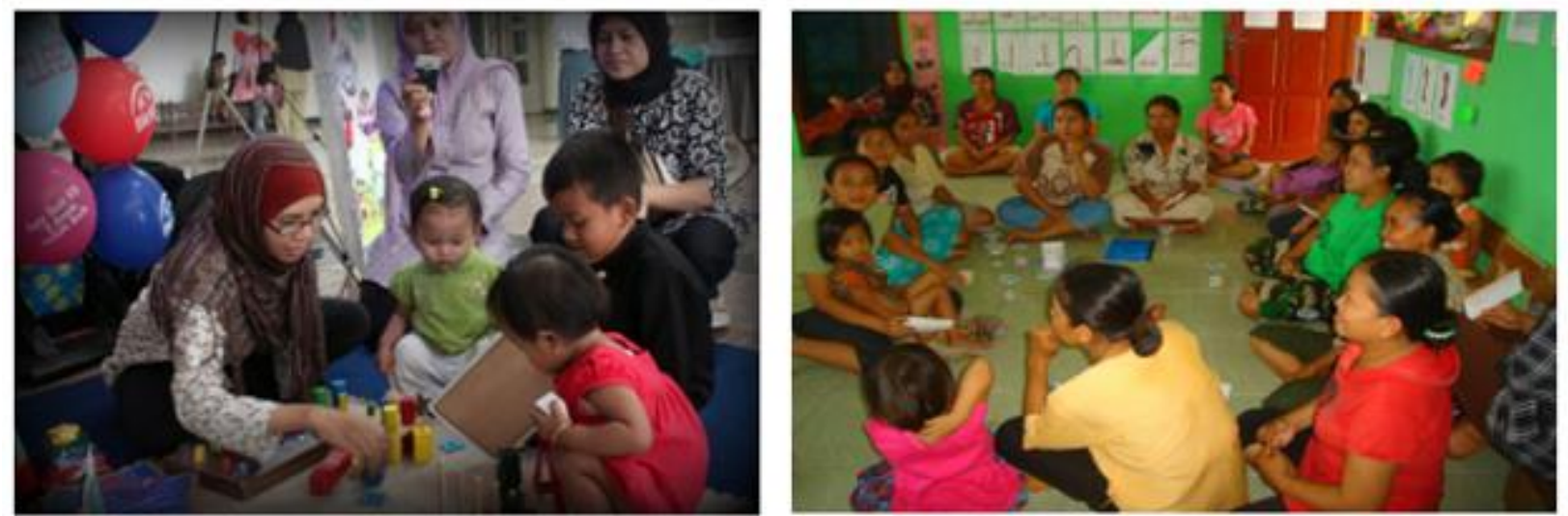

Gambar 2 Bina Keluarga Balita (BKB)

Hasil yang sudah dicapai dalam pelaksanaan Iptek Bagi Masyarakat (Pengabdian Masyarakat) terdapat beberapa hal, yaitu: pertama, adalah pengadaan alat Peraga edukatif/APE Alat Motorik kasar untuk siswa usia dini Pos PAUD berupa ayunan, jungkat-jungkit, tangga motorik / panjat jaring laba-laba, dan perosotan anak. 


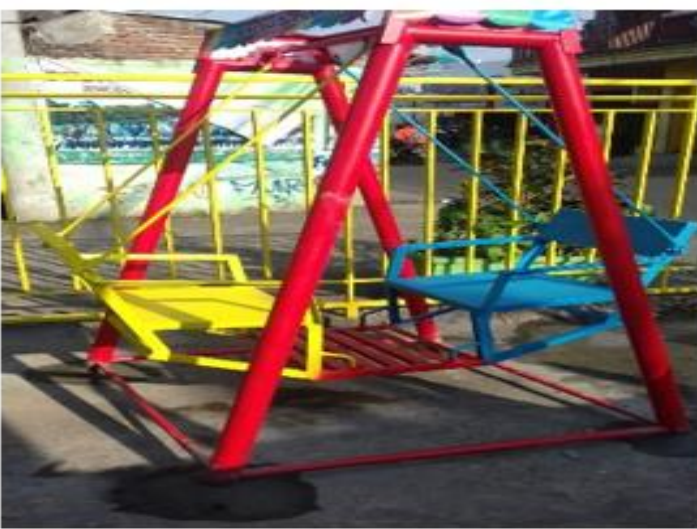

Gambar 4 Ayunan

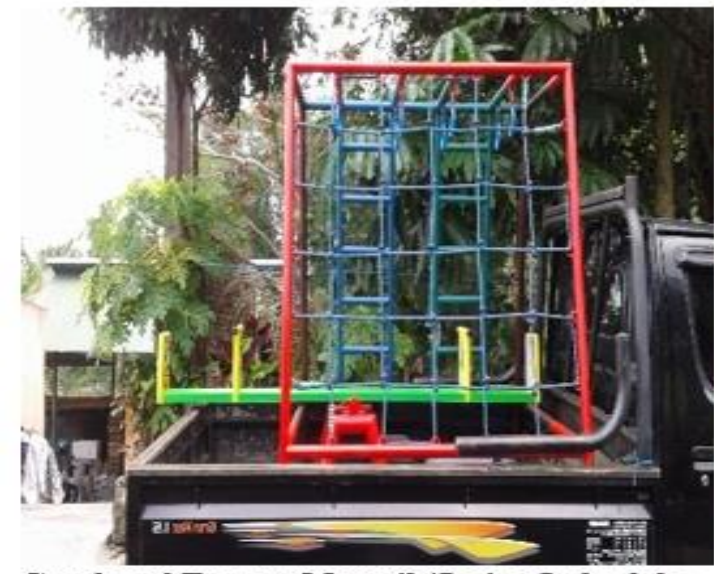

Gambar 6 Tangga Motorik/Jaring Laba-laba

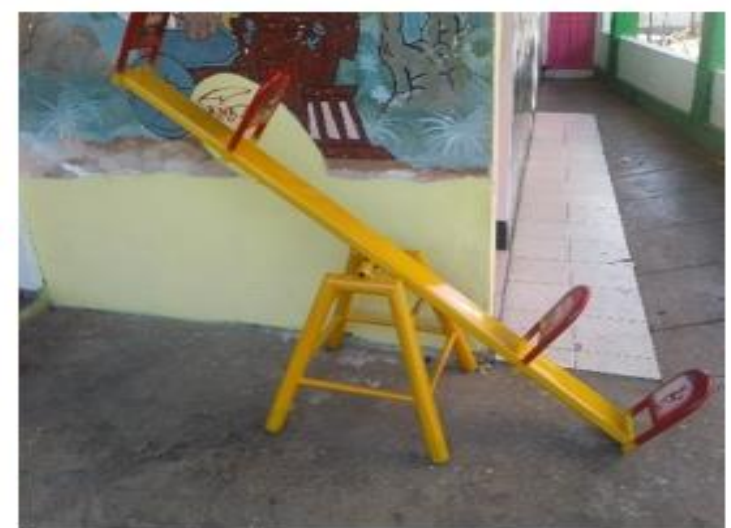

Gambax 5 Jungkat-jungkit

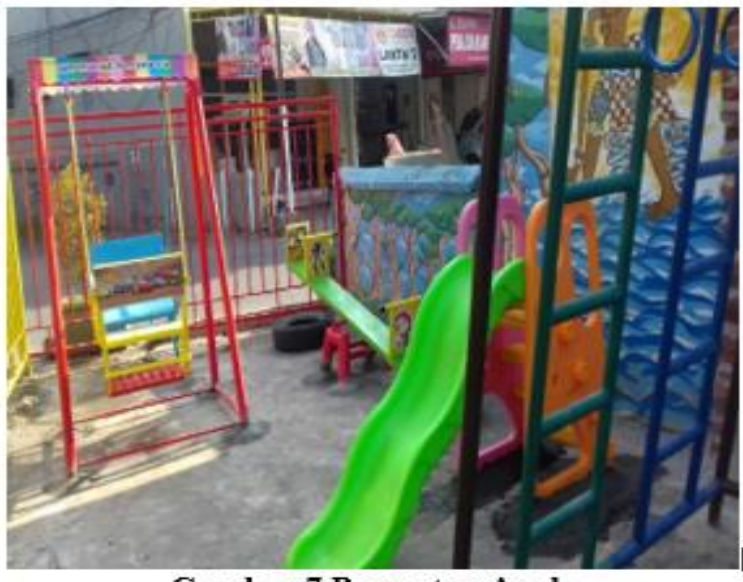

Gambar 7 Perosotan Anak

Kedua, adalah permohonan dan pengajuan dari mitra Pos PAUD mawar merah, bahwa untuk APE motorik kasar yang tersebut pada proposal yang meliputi: titian kesimbangan, tanjakan globe, tangga majemuk, papan luncur, untuk diganti dengan pengadaan pagar besi warna warni, sebagai pagar yang mengelilingi area bermain outdoor. Pagar besi tersebut ditujukan untuk melindungi atas keamanan siswa pos paud. Mengingat posisi tempat area sarana bermain outdoor siswa pos paud berdekatan dengan jalan raya. Atas permintaan Mitra dengan kesepakatan tim pelaksana, maka pengajuan mitra tersebut, diterima oleh Tim Pelaksana mengingat keberadaan pagar besi warna warni untuk keamanan siswa sangat urgen.
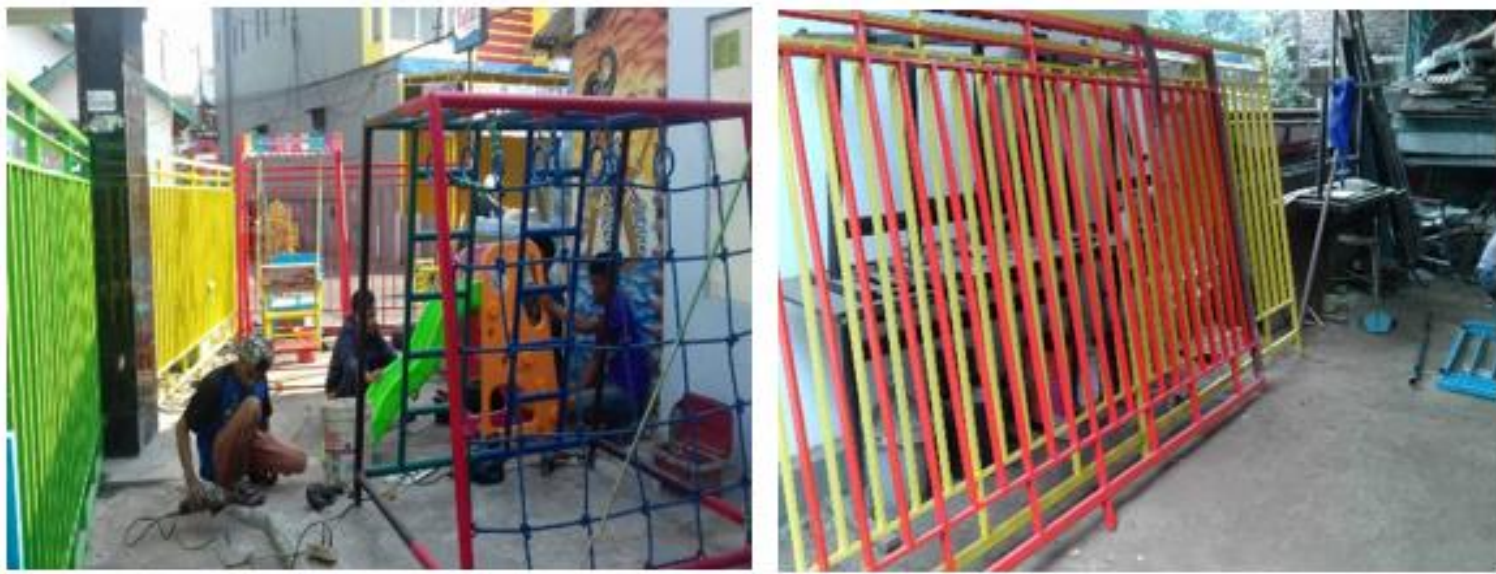

Gambar 8 Pagar besi warna warni 
Ketiga, Pengadaan meja kursi warna warni standard untuk siswa/siswi Pos PAUD.

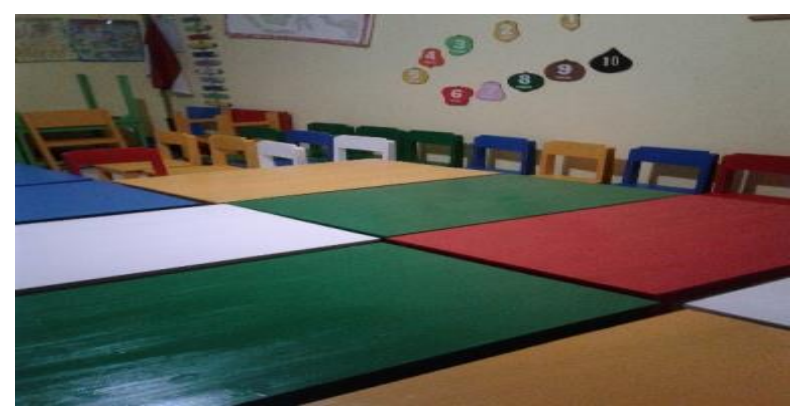

Gambar 9 Meja Kursi Warna Warni

Keempat, Pengadaan loker warna warni untuk siswa/siswi Pos PAUD

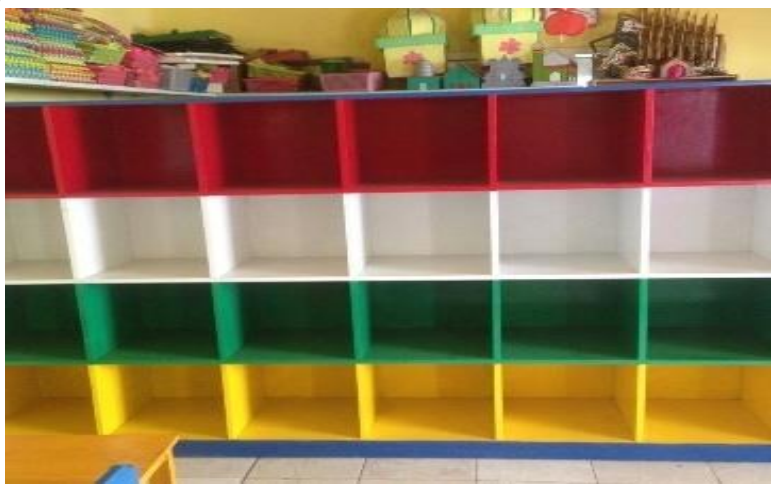

Gambar 10 LokerWarna Warni

\section{Simpulan dan Saran}

Kegiatan KKN-PPK Berjudul Pemberdayaan masayarakat Melalui Pengolahan Hasil Peternakan dan Perikanan sebagai Upaya dalam Menumbuhkan Jiwa Wirausaha di Desa Pombakka Kecamatan Malangke Barat Kabupaten Luwu Utara yang dilaksanakan mulai dari bulan Juli sampai dengan bulan Agustus 2018, dimana egiatan ini disambut dan diterima dengan baik oleh masyarakat secara umum terutama Ibu-Ibu PKK dengan bukti dukungan dan partisipasi dari segenap masyarakat Desa Pombakka Kecamatan Malangke Barat Kabupaten Luwu Utara. Melalui kegiatan pelatihan yang menghasilkan beberapa produk dengan memanfaatkan potensi dan sumber daya desa yang ada seperti produk Nugget Ikan, Nugget Ayam, Bakso Ikan dan Bakso Ayam sebagai kegiatan tambahan bagi kelompok masyarakat khsususnya ibu-ibu PKK Desa Pombakka Kecamatan Malangke Barat Kabupaten Luwu Utara. 


\section{Ucapan Terima Kasih}

Ungkapan terima kasih penulis ucapkan kepada Ketua Sekolah Tinggi Ilmu Ekonomi Muhammadiyah Palopo dan Ketua P3M Sekolah Tinggi Ilmu Ekonomi Muhammadiyah Palopo yang telah mewadahi penulis dalam melaksanakan program pengabdian masyarakat.Serta kepada Aparat Desa Pombakka dan ibu-ibu PKK Kecamatan Malangke BaratKabupaten Luwu Utara yang telah memberikan kerjasama yang baik sehingga kegiatan pengabdian Kuliah Kerja Nyata Pembelajaran Pemberdayaan Masyarakat (KKN-PPM) ini terlaksana dengan baik sesuai dengan waktu/jadwal pelaksanaan yang telah ditentukan sebelumnya berkat dukungan dana dari STIE Muhammadiyah Palopo Tahun 2018.

\section{Daftar Pustaka}

Kahan D. 2012.Entrepreneurship in Farming.Farm Management Extension Guide. Food and Agriculture Organization of The United Nations. Tersedia Pada: http://www.fao.org/docrep/018/i3231e/i3231e.pdf

Mcelwee G. 2006. Farmers as Entrepreneurs: Developing Competitive Skills. Journal Dev. Entrepreneurship.11(187) 2006.

Damihartini RS, Amri J. 2005.Hubungan Karakteristik Petani dengan Kompetensi Agribisnis pada Usahatani Sayuran di Kabupaten Kediri Jawa Timur. Jurnal Penyuluhan. September 2005. $1(1)$.

Dumasari. 2014. Kewirausahaan Petani Dalam Pengelolaan Bisnis Mikro di Pedesaan. Jurnal Inovasi dan Kewirausahaan. 3(3):196-202 September 2014. 